Економічні науки: збірник наукових прачь Луиького національного технічного університету. Серія "Регіональна економіка". Випуск 17 (67). Редкол.: відп. ред. к.е.н., професор І.В. Кривов’язюк. Луцьк: ІВВ Луцького НТУ, 2020. 348 с.

УДК 332.1

Баула О.В., к.е.н., доцент

Луцький національний технічний університет

\title{
КОНЦЕПТУАЛЬНІ ЗАСАДИ МІЖРЕГІОНАЛЬНОЇ ІНТЕГРАЦІЇ У РОЗВИТКУ ІННОВАЦІЙНИХ ПРОЦЕСІВ
}

В статті обгрунтовано актуальність активізації міжрегіонального співробітництва у інноваційній сфері, оскільки вона сприяє нівелюванню диспропорцій інноваційного розвитку в країні, а також формуванню ефективного та цілісного інноваційного простору. Обгрунтовується, що ефективність управління інноваційними процесами на регіональному рівні залежить від обліку змін, що відбуваються на макрорівні, а саме від обраної моделі інноваційного розвитку. Досліджено позиції України за складовими елементами Глобального інноваційного індексу за період 2015-2019 pp. Зважаючи на вузькі місця у вітчизняному інноваційному розвитку зазначено, що доцільним є впровадження передового світового досвіду міжрегіонального інноваційного співробітництва. Окреслено принципи міжрегіональної інтеграції інноваційних процесів.

Ключові слова: відкриті інновації, міжрегіональне співробітництво, управління інноваційними процесами, інтеграція.

\section{Baula O.}

\section{CONCEPTUAL PRINCIPLES OF INTERREGIONAL INTEGRATION IN THE DEVELOPMENT OF INNOVATIVE PROCESSES}

The article substantiates the urgency of intensifying interregional cooperation in the field of innovation, as interregional integration will help reduce the imbalances of innovation development in the country, as well as contribute to the formation of an effective and integrated innovation and network space.

It is substantiated that the effectiveness of management of innovation processes at the regional level depends on the accounting of changes occurring at the macro level, namely the chosen model of innovation development. European experience shows that currently the model of open innovation is developing in the direction of regional strategies of «smart specialization». In particular, it is assumed that each region / country should have its own innovation specialization according to the existing competitive advantages. At present, compliance with this condition is the main source of financial support from the Structural Investment Fund. At present, a significant number of programs of innovation initiatives and interregional cooperation in the field of innovation and research have been implemented and 
Економічні науки: збірник наукових прачь Луиького національного технічного університету. Серія "Регіональна економіка". Випуск 17 (67). Редкол.: відп. ред. к.е.н., професор І.В. Кривов’язюк. Луцьк: ІВВ Луцького НТУ, 2020. 348 с.

continue to be implemented in the EU. Among them: INTERREG, Horizon 2020, Joint Technology Initiatives (JTI). European Innovation Partnerships (EIP), etc.

Currently, the real economic situation, the level of competitiveness and investment in Ukraine want to be better due to the high level of shadowing and a significant degree of regulation of business intensification. This state of the domestic economy proves that the potential of available resources is almost exhausted and to achieve significant positive changes is possible only if the formation and implementation of an adequate innovative model of national economy, taking into account world best practices in this area, and development strategies to world market.

Ukraine's position on the constituent elements of the Global Innovation Index for the period 2015-2019 is studied. According to the results of the ranking of 129 countries according to the components of GII-2019, Ukraine occupies the best positions in the world according to the following indicators: according to the created utility models; for the employment of women with academic degrees; by the number of students per teacher in high school; by created trademarks; 8th place according to the created industrial designs. The worst positions of Ukraine according to the results of GII-2019 are recorded by sub-indices of the state of the institutional environment (political, regulatory, business), infrastructure development and the internal market. Also, for several years in a row, the critical value (1\% of GDP) of the research expenditure indicator, namely in the range of $0,6-0,7 \%$ of GDP.

The principles of interregional integration of innovation processes are outlined: integration of all regions of the country into a single integrated system for multiplying joint innovation development; a combination of centralized management of innovation processes at the national level and self-government at the regional level; minimization of risks and threats of loss of competitiveness from openness of regions; coordination of interests through the interregional coordinating institute concerning positions of regions in interregional management of innovative activity.

Key words: open innovations, interregional cooperation, management of innovation processes, integration.

Баула Е.В.

\section{КОНЦЕПТУАЛЬНЫЕ ОСНОВЫ МЕЖРЕГИОНАЛЬНОЙ ИНТЕГРАЦИИ В РАЗВИТИИ ИННОВАЦИОННЫХ ПРОЦЕССОВ}

В статье обоснована актуальность активизации межрегионального сотрудничества в инновационной сфере, поскольку оно способствует нивелированию диспропорций инновационного развития в стране, а также формированию эффективного и целостного инновационного пространства. Обосновывается, что эффективность управления инновационными процессами на региональном уровне заключается в учете изменений, происходящих на макроуровне, а именно от выбранной модели инновационного развития. 
Економічні науки: збірник наукових прачь Луиького національного технічного університету. Серія "Регіональна економіка". Випуск 17 (67). Редкол.: відп. ред. к.е.н., професор І.В. Кривов'язюк. Луиьк: ІВВ Луцького НТУ, 2020. 348 с.

Исследована позиции Украины по составляющим элементам Глобального инновационного индекса за период 2015-2019 гг. Учитывая узкие места в отечественном инновационном развитии указано, что целесообразным является внедрение передового мирового опыта межрегионального инновационного сотрудничества. Определены принципы межрегиональной интеграции инновационных процессов.

Ключевые слова: открытые инновации, межрегиональное сотрудничество, управление инновационными процессами, интеграция.

\section{Постановка проблеми у загальному вигляді та їі зв'язок з важливими науковими і практичними завданнями. \\ Сучасні глобалізаційні соціально-економічні} трансформації перетворюють здатність до ефективної мобільності у фактично єдиний показник рівня розвитку бізнесдіяльності. Серед новітніх виявів подібної мобільності доцільно виокремити швидкість реакції на змінність кон'юнктурних умов макро- та мегарівнів, реакцію на поширення змін інституціонального середовища, продукування сучасним ринком елементів асиметрії інформації i т.п. Рівень динамічності розвитку конкурентних відносин, глобалізації світогосподарських процесів зумовлюють необхідність розбудови інноваційної моделі розвитку, як найуспішнішої i найперспективнішої.

Питання необхідності реалізації відкритої моделі інноваційного розвитку актуалізуються під впливом розширення спеціалізації суб'єктів інноваційної діяльності, широкого розповсюдження інформаційно-комунікаційних технологій, мережева організація інноваційного середовища. Інноваційні ідеї потребують, як правило, унікальних ресурсів або їх комбінації. Саме тому, за умови дефіциту або обмежених обсягів ресурсів, суб'єкти інноваційної діяльності змушені їх відшуковувати у зовнішньому середовищі. Як наслідок, нарощення інноваційного потенціалу видається неможливим без розвитку інтеграційних процесів, як на мікро-, макро- так i мегарівнів.

Розглядаючи макрорівень, доцільним є припущення про те, що міжрегіональна інтеграція сприятиме нівелюванню 
Економічні науки: збірник наукових прачь Луиького національного технічного університету. Серія "Регіональна економіка". Випуск 17 (67). Редкол.: відп. ред. к.е.н., професор І.В. Кривов'язюк. Луиьк: ІВВ Луцького НТУ, 2020. 348 с.

диспропорцій інноваційного розвитку в країні, а також сприятиме формуванню ефективного та цілісного інноваційномережевого простору.

Bce вище зазначене актуалізує проблематику концептуальних засад міжрегіональної інтеграції щодо забезпечення ефективних інноваційних процесів.

Аналіз останніх досліджень у яких започатковано вирішення проблеми. Роль інновацій у процесі забезпечення конкурентоспроможності національної економіки розглядали у своїх наукових працях вітчизняні та зарубіжні вчені: І. Алєксєєв, Б. Буркинський, О. Виноградова, П. Друкер, Б. Йонсон, Дж. М. Кейнс, О. Кузьмін, В. Геєць, А. Маршал, Л. Омелянович, М. Портера, А. Поручник, К.А. Садєков, Дж. Сакс, П. Самуельсон, Б. Скотт, М. Туган-Барановський, І. Фішер, К. Штальман, Й. Шумпетер та ін.

Теоретико-методологічні аспекти відкритих інновацій знайшли своє відображення у роботах Е. Enkel, Н. Meer, J. Christensen, C. Bloch, E. Velde, J. West та ін.

Різноманітним аспектам дослідження міжрегіональної взаємодії присвячені праці вітчизняних та зарубіжних вчених: О. Абрамової, М. Біганової, Ю. Дубровської, С. Кузнєцова, С. Макаричева, В. Покровського, В. Хоменко, Р. Ягудаєва та ін.

Однак, попри наявність глибоких і грунтовних наукових опрацювань у зазначених сферах, проблематика вироблення концепції міжрегіонального інноваційного співробітництва досліджена не на достатньому рівні.

Цілі статті: обгрунтування ролі міжрегіональної інтеграції у активізації інноваційних процесів.

Виклад основного матеріалу дослідження 3 повним обгрунтуванням отриманих наукових результатів. В економічній літературі є твердження про те, що міжрегіональна інтеграція являє собою об'єднання виробничих процесів двох та більше регіонів, яке перетворює їх на цілісний господарський механізм, що характеризується систематичністю зв'язків i появою нових інтеграційних рівнів національного управління $[1 ; 2]$. Саме тому, міжрегіональна інтеграція зумовлює не лише 
Економічні науки: збірник наукових прачь Луиького національного технічного університету. Серія "Регіональна економіка". Випуск 17 (67). Редкол.: відп. ред. к.е.н., професор І.В. Кривов'язюк. Луиьк: ІВВ Луцького НТУ, 2020. 348 с.

міжрегіональну співпрацю, а й інституційне їх оформлення через формування нових інститутів управління, регламентування, забезпечення і т.п.

Ефективність управління інноваційними процесами на регіональному рівні залежить від обліку змін, що відбуваються на макрорівні, а саме від обраної моделі інноваційного розвитку.

Європейський досвід свідчить, що на даний час модель відкритих інновацій розвивається в напрямі регіональних стратегій «розумної спеціалізації» (RIS3 - являє собою плани, розроблені на регіональному та національному рівнях $\mathrm{CC}$, які окреслюють пріоритетні інноваційні, дослідні та економічні напрями розвитку регіонів і країн) [3]. Зокрема, передбачається, що кожен регіон / країна повинні мати власну інноваційну спеціалізацію згідно наявних конкурентних переваг. На даний час саме дотримання цієї умови $€$ основною отримання фінансової підтримки від Структурного інвестиційного фонду.

На даний час на території ЄС реалізовано та продовжує реалізовуватись значна кількість програм інноваційних ініціатив та міжрегіонального співробітництва у сфері інновацій та досліджень. Серед яких: INTERREG, Horizon 2020, Спільні технологічні ініціативи (JTI). Свропейські інноваційні партнерства (EIP) i т.п. Також, як приклад ефективної міжрегіональної інноваційної співпраці, реалізованої на теренах ЄC, можна назвати програму EURIS (європейські відкриті регіональні інноваційні стратегіi): п’ять європейських регіонів 3 Іспанії (Наварра), Німеччини (Штутгартський регіон), Нідерландів (організація економічного розвитку Brainport Development), Угорщини (Західна Трансданубія), Польщі (Лодзинське воєводство) об'єднались для спільної пропозиції ресурсів та інструментів, що сприяли б впровадженню відкритих інновацій; розповсюдження передового досвіду, нових моделей та рекомендацій, а також формування рекомендацій для інших регіонів, що зацікавлені у відкритті своїх інноваційних систем [4; 5].

На даний час, реальна економічна ситуація, рівень конкурентоспроможності та обсяги капіталовкладень в Україні 
Економічні науки: збірник наукових прачь Луиького національного технічного університету. Серія "Регіональна економіка". Випуск 17 (67). Редкол.: відп. ред. к.е.н., професор І.В. Кривов'язюк. Луиьк: ІВВ Луцького НТУ, 2020. 348 с.

бажають бути кращими через високий рівень тінізації і значний ступінь зарегульованості процесів активізації підприємницької діяльності. Даний стан вітчизняної економіки доводить те, що потенціал наявних ресурсів практично вичерпано і досягнути суттєвих позитивних зрушень можливо лише за умови формування та впровадження адекватної інноваційної моделі розвитку національного господарства 3 врахування передового світового досвіду в даній царині і стратегії розвитку щодо формування належного рівня конкурентоспроможності на світовому ринку. Під впливом глобальних соціальноекономічних трансформацій, підвищення рівня конкуренції на світовому ринку, процесів транснаціоналізації, розвитку індустрії 4.0, мережевізації та цифрової інтеграції виробничих процесів на початку XXI ст. саме активізація повноцінної науково-інноваційної діяльності є тим за пусковим механізмом, якому під силу забезпечити інтенсивне економічне зростання в країні, підвищити ефективність виробництва, конкурентоспроможність продукції та добробут громадян.

На підтвердження необхідності системної модернізації технологічно-інноваційного базису виробництва на національному, регіональному та світовому рівнях можна навести дані про те, що на даний час від $70 \%$ до $85 \%$ ВВП розвинутих країн світу формується на основі нових знань, що втілюються у товарах, технологіях, організації виробництва [6, c. 214].

На жаль, аналіз динаміки інноваційного розвитку країн світу та статистика останніх років дає можливість зробити висновок про те, що вітчизняна економіка характеризується кризовими проявами в інноваційній сфері.

Досліджуючи позиції України за складовими елементами Глобального інноваційного індексу за період 2015-2019 рр. (таблиця 1) можна зробити висновок про певне поліпшення ситуації у 2015-2018 рр. та погіршення у 2019 р.

Так, Україна в рейтингу 2015 р. знаходилась на 64-й позиції з рівнем інновацій 36,5 бали зі 100 можливих, за підсумками 2016 р. Україна піднялась на 8 позицій відносно 
Економічні науки: збірник наукових пращь Луцького національного технічного університету. Серія "Регіональна економіка". Випуск 17 (67). Редкол.: відп. ред. к.е.н., професор І.В. Кривов’язюк. Луцьк: ІВВ Луцького НТУ, 2020. 348 с.

2015 р. і посіла 56 місце $з$ балом 35,7, у 2017 р. - 50 місце у рейтингу з балом 37,9 , у 2018 р. - 43 місце з балом 38,5, а у 2019 році Україна відносно 2018 року втратила 4 позиції i опустилась на 47 місце з балом 37,4 [7].

Таблиця 1

Позиціонування України в рейтингу Глобального індексу інновацій за 2015-2019 pр.

\begin{tabular}{|c|c|c|c|c|c|c|c|c|c|c|}
\hline \multirow[b]{2}{*}{ Складові ГІІ } & \multicolumn{2}{|c|}{2015} & \multicolumn{2}{|c|}{2016} & \multicolumn{2}{|c|}{2017} & \multicolumn{2}{|c|}{2018} & \multicolumn{2}{|c|}{2019} \\
\hline & $\cdot \stackrel{\mathscr{0}}{\overrightarrow{0}}$ & డ్రి & $\cdot \stackrel{\mathscr{v}}{\Sigma}$ & ర్ & $\cdot \stackrel{0}{E}$ & ర్ర్రి & $\cdot \stackrel{\mathscr{0}}{\mathscr{e}_{\Sigma}}$ & డ్ & $\cdot \stackrel{\mathscr{0}}{\sum}$ & ర్ \\
\hline $\begin{array}{c}\text { Глобальний індекс } \\
\text { інновацій }\end{array}$ & 64 & 36,5 & 56 & 35,7 & 50 & 37,9 & 43 & 38,5 & 47 & 37,4 \\
\hline $\begin{array}{c}\text { Субіндекс «Входу» } \\
\text { (Innovation Input) }\end{array}$ & 84 & 39,1 & 76 & 38,9 & 77 & 41,0 & 75 & 40,5 & 82 & 40,7 \\
\hline $\begin{array}{l}\text { Розвиток внутрішнього } \\
\text { ринку }\end{array}$ & 89 & 43,9 & 75 & 42,1 & 81 & 43,2 & 89 & 42,7 & 90 & 43,3 \\
\hline Розвиток інфраструктури & 112 & 26,3 & 99 & 32,3 & 90 & 39,3 & 89 & 38,1 & 97 & 36,0 \\
\hline Розвиток бізнесу & 78 & 32,4 & 73 & 30,6 & 51 & 35,3 & 46 & 34,5 & 47 & 34,8 \\
\hline $\begin{array}{l}\text { Стан розвитку людського } \\
\text { капіталу та науки }\end{array}$ & 36 & 40,4 & 40 & 40,8 & 41 & 39,6 & 43 & 37,9 & 51 & 35,6 \\
\hline $\begin{array}{l}\text { Стан iнституційного } \\
\text { середовища (політичного, } \\
\text { регуляторного, } \\
\text { бізнесового) }\end{array}$ & 98 & 52,2 & 101 & 48,7 & 101 & 47,9 & 107 & 49,1 & 96 & 53,9 \\
\hline $\begin{array}{c}\text { Субіндекс «Виходу» } \\
\text { (Innovation Output) }\end{array}$ & 47 & 33,9 & 40 & 32,5 & 40 & 34,2 & 35 & 36,6 & 36 & 34,1 \\
\hline $\begin{array}{l}\text { Результати } \\
\text { діяльності }\end{array}$ & 75 & 31,3 & 58 & 31,0 & 49 & 35,6 & 45 & 36,5 & 42 & 33,5 \\
\hline $\begin{array}{l}\text { Розвиток технологій та } \\
\text { економіки знань }\end{array}$ & 34 & 36,4 & 33 & 34,1 & 32 & 32,8 & 27 & 36,7 & 28 & 34,6 \\
\hline $\begin{array}{c}\text { Коефіціснт інноваційної } \\
\text { ефективності }\end{array}$ & 15 & 0,9 & 12 & 0,8 & 11 & 0,8 & 5 & 0,9 & 10 & 0,8 \\
\hline
\end{tabular}

Джерело: [8; 9; 10].

За результатами рейтингування 129 країн за складовими ГII-2019 Україна займає найкращі позиції в світі за наступними індикаторами: 1 місце за створеними корисними моделями; 2 місце за працевлаштуванням жінок 3 вченими ступенями; 
Економічні науки: збірник наукових прачь Луиького національного технічного університету. Серія "Регіональна економіка". Випуск 17 (67). Редкол.: відп. ред. к.е.н., професор І.В. Кривов'язюк. Луиьк: ІВВ Луцького НТУ, 2020. 348 с.

3 місце за кількістю учнів на одного вчителя в середній школі; 6 місце за створеними торговими марками; 8 місце за створеними промисловими зразками.

Найгірші позиції України за результатами ГІІ-2019 зафіксовані за підіндексами стану інституційного середовища (політичного, регуляторного, бізнесового), розвитку інфраструктури та внутрішнього ринку. Також декілька років поспіль є критичним значення (1\% ВВП) показника витрат на наукові дослідження, а саме в межах 0,6-0,7\% ВВП.

Зважаючи на вузькі місця у вітчизняному інноваційному розвитку доцільним $\epsilon$ впровадження передового світового досвіду міжрегіонального інноваційного співробітництва.

Формування механізму міжрегіональної інтеграції інноваційних процесів повинне базуватись на наступних принципах:

- інтеграція усіх регіонів країни у єдину цілісну систему для мультиплікування спільного інноваційного розвитку;

- поєднання централізованого управління інноваційними процесами на рівні країни та самоуправління на рівні регіону;

- мінімізація ризиків та загроз втрати конкурентоспроможності від відкритості регіонів;

- узгодження інтересів через міжрегіональний координуючий інститут стосовно позицій регіонів у міжрегіональному управлінні інноваційною діяльністю.

Висновки. Таким чином, реалізація в Україні концепції міжрегіонального інноваційного співробітництва повинна базуватися на формуванні кластерних структур, що дасть змогу розширити межі економічної активності територіальноадміністративних одиниць шляхом стимулювання співробітництва та кооперації. Однак впровадження даних процесів потребує відповідної законодавчої та методологічної бази, що необхідна для організаційно-економічної та інституційної регламентації.

Реалізація розглянутого механізму інтеграції інноваційних процесів дозволить задіяти потенціал міжрегіональної взаємодії в системі управління відкритими інноваціями, активізувати 
Економічні науки: збірник наукових прачь Луиького національного технічного університету. Серія "Регіональна економіка". Випуск 17 (67). Редкол.: відп. ред. к.е.н., професор І.В. Кривов'язюк. Луиьк: ІВВ Луцького НТУ, 2020. 348 с.

процеси нівелювання регіональної диспропорції розвитку, що дасть змогу підвищити рівень конкурентоспроможності вітчизняної економіки.

\section{Список бібліографічного опису}

1. Биганова М.А. Межрегиональная интеграция как фактор конкурентного развития макроэкономического пространства. Terra Economicus. 2012. Том 10. №1. Часть 3. URL: https://cyberleninka.ru/article/n/mezhregionalnaya-integratsiya-kak-faktorkonkurentnogo-razvitiya-mezoekonomicheskogo-prostranstva/viewer (дата зверенення: 20.08.2020).

2. Дубровская Ю.В. Инструменты и институты активизации межрегионального взаимодействия в отечественной экономике. Вестник Омского университета. Серия «Экономика». 2017. № 4 (60). URL: https://cyberleninka.ru/article/n/instrumenty-i-instituty-aktivizatsii-mezhregionalnogovzaimodeystviya-v-otechestvennoy-ekonomike/viewer (дата зверенення 20.08.2020).

3. National/Regional Research and Innovation Strategies for Smart Specialisation (RIS3). European Commission: Website. 2014. URL: https://ec.europa.eu/regional_policy/sources/docgener/inf ormat/2014/smart_specialisation en.pdf (дата зверенення 28.08.2020).

4. Elvira Uyarra, Jens Sörvik, Inger Midtkandal. Inter-regional Collaboration in Research and Innovation Strategies for Smart Specialisation (RIS3). European Commission. S3 Working Paper Series. № 6. 2014. URL. https://s3platform.jrc.ec.europa.eu/documents/20182/114903/JRC91963_Interreg_C ollaboration_RIS3_final.pdf/89b7b310-8378-4e03-bcd9-2680061d037e (дата звернення: 20.09.2020).

5. Regional benchmarking in the smart specialisation process: Identification of reference regions based on structural similarity : S3 Working Paper Series № 03 / Navarro M., Gibaja J., Franco S., Murciego A., Gianelle C., Hegyi F., Kleibrink A. European Commission: Joint Research Centre, 2014. 36 p. URL: http://s3platform.jrc.ec.europa.eu/documents/20182/114903/JRC89819_RegionalBench marking.pdf/699a6115-f685-4567-969d-921d116a304e (дата зверенення 21.09.2020).

6. Ніколаєнко А.І. Вплив глобалізації на ефективність регулювання інноваційної моделі розвитку. Управління економікою: теорія та практика: Зб. наук. $n p$. К.: ІЕП НАНУ, 2015. С. 208-221.

7. Global innovation index - 2019. Creating Healthy Lives-The Future of Medical Innovation. URL: https://www.wipo.int/edocs/pubdocs/en/wipo pub gii 2019.pdf (дата звернення: 29.03.2020).

8. The Global Innovation Index. Retrieved from. URL: http://www.wipo.int/publications/en// details.jsp?id=4193\&plang=EN (дата звернення: 29.03.2020).

9. Аналітична довідка про стан інноваційної діяльності України. URL: https://mon.gov.ua/storage/app/media/innovatsii-transfer-tehnologiy/monitoringprioritet/ stan-id-2017-f.pdf (дата звернення: 29.03.2020). 
Економічні науки: збірник наукових прачь Луиького національного технічного університету. Серія "Регіональна економіка". Випуск 17 (67). Редкол.: відп. ред. к.е.н., професор І.В. Кривов’язюк. Луцьк: ІВВ Луцького НТУ, 2020. 348 с.

10. Global innovation index - $2018 . \quad$ URL: https://www.wipo.int/edocs/pubdocs/en/wipo_pub_gii_2018.pdf (дата звернення: 29.03.2020).

\section{References}

1. Byhanova M.A. Mezhrehyonalnaia yntehratsyia kak faktor konkurentnoho razvytyia makroэkonomycheskoho prostranstva. Terra Economicus. 2012, Vol. 10, No.1, Chast 3. Available at: https://cyberleninka.ru/article/n/mezhregionalnaya-integratsiya-kakfaktor-konkurentnogo-razvitiya-mezoekonomicheskogo-prostranstva/viewer (accessed 20.08.2020) [In Russsian].

2. Dubrovskaia Yu.V. Ynstrumentы y ynstytutы aktyvyzatsyy mezhrehyonalnoho vzaymodeistvyia $\mathrm{v}$ otechestvennoi эkonomyke. Vestnyk Omskoho unyversyteta. Seryia "Эkonomyka". 2017, No. 4 (60). Available at: https://cyberleninka.ru/article/n/instrumenty-i-instituty-aktivizatsii-mezhregionalnogovzaimodeystviya-v-otechestvennoy-ekonomike/viewer $\quad$ (accessed 20.08.2020) [In Russsian].

3. National/Regional Research and Innovation Strategies for Smart Specialisation (RIS3). European Commission: Website. 2014. Available at: https://ec.europa.eu/regional_policy/sources/docgener/informat/2014/smart_ specialisation _en.pdf (accessed 20.08.2020).

4. Elvira Uyarra, Jens Sörvik, Inger Midtkandal. Inter-regional Collaboration in Research and Innovation Strategies for Smart Specialisation (RIS3). European Commission. S3 Working Paper Series. 2014, No.6. Available at: https://s3platform.jrc.ec.europa.eu/documents/20182/114903/JRC91963_Interreg_Collabor ation_RIS3_final.pdf/89b7b310-8378-4e03-bcd9-2680061d037e (accessed 20.09.2020).

5. Navarro M., Gibaja J., Franco S., Murciego A., Gianelle C., Hegyi F., Kleibrink A. Regional benchmarking in the smart specialisation process: Identification of reference regions based on structural similarity, S3 Working Paper Series No. 03, European Commission, Joint Research Centre, 2014, 36 p. Available at: http://s3platform.jrc.ec.europa.eu/documents/20182/114903/JRC89819_Regional Benchmarking.pdf/699a6115-f685-4567-969d-921d116a304e (accessed 21.09.2020).

6. Nikolayenko A.I. Vplyv hlobalizatsiyi na efektyvnist' rehulyuvannya innovatsiynoyi modeli rozvytku. Upravlinnya ekonomikoyu: teoriya ta praktyka: Zb. nauk. pr. K.: IEP NANU, 2015. pp. 208-221 [in Ukrainian].

7. Global innovation index - 2019. Creating Healthy Lives-The Future of Medical Innovation. Available at: https://www.wipo.int/edocs/pubdocs/en/wipo _pub gii 2019.pdf (accessed 29.03.2020).

8. The Global Innovation Index. Retrieved from. Available at: http://www.wipo.int/publications/en/details.jsp?id=4193\&plang=EN (accessed 29.03.2020).

9. Analitychna dovidka pro stan innovatsiynoyi diyal'nosti Ukrayiny. Available at: https://mon.gov.ua/storage/app/media/innovatsii-transfer-tehnologiy/monitoringprioritet/ stan-id-2017-f.pdf (accessed 29.03.2020) [in Ukrainian].

10. Global innovation index - 2018. Available at: https://www.wipo.int/edocs/pubdocs/en/wipo_pub_gii_2018.pdf (accessed 29.03.2020). 